\title{
ENVIRONMENTAL EDUCATION: POLICY AND PRACTICE http://dx.doi.org/10.5902/2176217111716
}

\author{
Mihaela lacob \\ Independent researcher, Manitoba - Canada.
}

\begin{abstract}
This paper seeks to uncover the realities behind the integration, or lack thereof, of Environmental Education into the core science curriculum as well as suggestions to successfully integrating it. There is an urgent need for transformative environmental education and action-based environmental participation, concerns also echoed by the international community. The schools should be vested with an environmental mission about/for/in the environment. Educational legislation for science education and practice are bridged by a myriad of difficulties to successfully integrating it (Hart, 2002; Metz et al., 2010). Effective strategies for integration as well as teachers' preparedness and professional development are among the steps towards successful integration. Key-words: Environmental education, science education, knowledge mobilization, scientificallyliterate citizens, teachers' professional development.
\end{abstract}

\section{EDUCAÇÃO AMBIENTAL: POLÍTICA E PRÁTICA}

\section{Resumo}

Neste trabalho procura-se desvendar a realidade por trás da integração, ou falta dela, da Educação Ambiental no currículo de ciências básicas, bem como apresentar sugestões para a sua integração bem sucedida. Há necessidade urgente da Educação Ambiental e de uma ação transformadora baseada na participação do meio ambiente, em acordo com a comunidade internacional. As escolas devem investir em uma missão ambiental sobre/para/no meio ambiente. A legislação educacional para o ensino e a prática da ciência encontra uma miríade de dificuldades para ser integrada com sucesso (Hart, 2002; Metz et al., 2010). Estratégias eficazes para a integração, bem como a preparação dos professores e desenvolvimento profissional, são passos no sentido da integração bem sucedida.

Palavras-chave: educação ambiental, educação científica, mobilização do conhecimento, cidadãos cientificamente alfabetizados, desenvolvimento profissional dos professores. 


\section{Introduction}

Among the aims of science education is to create scientifically- and politically- literate citizens that engage in socially- and environmentally-based issues (Hodson, 2010). While some researchers argue for a broadening of science curriculum to include an STSE emphasis, others are in favour of the critical- knowledge base essential for functioning in the market-driven economy (Hodson, 2010).

What are the ingredients that contribute to the development of scientific literacy? Understanding the nature of science? Possessing the knowledge-base of the major theoretical frameworks and a thorough understanding of the historical background of science? The use of science-related critical thinking skills on a daily basis? Or, all of the above and action-oriented initiatives towards the welfare of the environment?

A scientifically-literate citizen is "able to combine science knowledge with the ability to draw evidence-based conclusions in order to understand and help make decisions about the natural world and the changes made to it through human activity (OECD, 1998, p. 5). Or, as Hodson (2011) stated, scientifically-literate citizens are critical consumers of scientific information and capable of participating in the decision-making process on socioscientific issues "that affect their health, security and economic well-being" (p. 5). In this context, environmental education, whether it is offered as a stand-alone course or incorporated within a disciplinary base or offered as part of an STSE emphasis of science education has the imperative goal of developing critical thinkers that are capable of making decisions about the environment and understanding the intricacy between science, technology, and society. The goal of scientific literacy is to develop active citizenry, or, "responsible citizenship", and to enhance democracy (Hodson, 2011).

\section{The role of environmental education}

Environmental education is a means through which to foster "environmentally responsible attitudes and behaviours", but it is also a way of inculcating no anthropocentrism (the belief in the inherent value of nature or in the goodness of valuing nature for its own sake) (Ferkany; Whyte, 2013, p. 6). Environmental education should be transformative in nature (Gough; Sharply, 2005; Ferkany; Whyte, 2013) and it should arm students with "the skills and expertise to tackle the enormous complexity of contemporary environmental problems" (Molsemi et al., 2009, p. 514). Environmental education has the potential to become transformative, but it depends on the teachers' beliefs (Hart, 2002), level of comfort in teaching environmental issues (Mertz, 2010; Gough; Sharpley, 2005), space in an overcrowded curriculum (Mertz, 2010; Gough; Sharpley, 2005), and networking with community stakeholders.

The research does indicate that actively involving teachers in curriculum development through praxis does challenge them to take a critical look at their own teaching and teaching objectives (Wals; Albas, 1997, p. 265 in Gough and Sharpley, 2005, p. 196).

\section{Legislation in Ontario}

The Science in Society course introduced in Ontario high schools in 1988 and that had an STSE emphasis was discontinued in 2003 and, instead, STSE was infused across grades, subjects, and disciplines (Barret; Pedretti, 2006). This new STSE orientation of the 
high school curricula only placed heavy emphasis on "technology and industry" and didn't explore or analyse the interaction between society, science, and technology. New developments in research at an international level brought with it a flurry of debates on the introduction of $E E$ as part of the curriculum.

In 2007, the Ontario Ministry of Education released two documents that mandated the introduction of EE across the curriculum. The report entitled Shaping our Schools, Shaping our Future (aka the Bondar Report) stressed the need to incorporating environmental education across the curricula and grades. In 2008, a new revised Science Curriculum mandated the introduction of EE into the science curriculum (Steele, 2010). These changes have brought with it a new wave of debates as EE and Science education are two divergent disciplines that cannot be merged together. Steele (2010) argued that environmental education is politically-and socially -charged while science education is viewed as an empirical, free-of bias discipline. Yet, Hodson (2009) in the article entitled The history, traditions and values of science stated that the view of science as a free-of bias and rigid discipline is a myth. He argued that scientists are not isolated from bias: "because scientists draw ideas from their cultural location, and are strongly influenced by the values that underpin society at any particular time, there is the ever-present danger of bias and distortion" (Hodson, 2009, p. 336). The view that EE is politically - and socially charged is grounded in critical pedagogy which is "based on socially-constructivist, transformative and participatory approaches. This requires teaching and learning methods that promote a critical and a reflective perspective in their learners" (Pouliot, 2009, p. 180). The myth that science is free of bias is based on a Western positivist paradigm that is grounded in a reductionist approach (Steele, 2010).

\section{The situation in Ontario, Canada}

The curricular ideologies that have dominated science education are changing in light of new developments of learning theories, systemic reforms, research on science teaching and learning, and professional development (Hart, 2002). Although from its incipient phases, the introduction of environmental education has been regarded as a strenuous endeavour, it has nevertheless been slowly integrated into the science curriculum.

The implementation of environmental education at the school level still remains a challenge for many teachers despite enacted legislation (Hart, 2002; Metz et al., 2010). For instance, the integration of environmental education into the science curriculum was enunciated in the 1993 Pan-Canadian science curriculum and Pan-Canadian Framework of Science Learning Outcomes (CMEC, 1997) (Hart, 2002) which was grounded in an STSE framework. The aim of the science curriculum was to "prepare students to critically address science - related societal, economic, ethical, and environmental issues" (CMEC, 1997, p. 5). In 2003, the Ministry of Education in Ontario mandated the integration of environmental science into core curriculum (Metz et al., 2010).

The relationship between policy and practice is weak. A study conducted by Puk and Behm (2003) on the implementation of environmental education in Ontario schools revealed issues with implementation. The interviewed teachers argued that the introduction of ecological topics presented challenges in an already crowded curriculum.

In most provinces, environmental education is injected into the science curriculum or under overarching subjects such as STSE, Education for Education for Environment, or 
Education for Sustainable Development (ESD). As it if often the case, EE has problems of positionality within a discipline-oriented curriculum which is based on a social reproduction model (Barret; Peddretti, 2006).

Should environmental education be integrated into the science curriculum or should it establish itself as a new discipline?

Research studies have shown that environmental education as a stand-alone discipline devotes more time to critically examining environmental issues as opposed to being integrated into science education (Mertz et al., 2010). Environmental education has to include education about, for, and in the environment (Mertz, 2010). Education about and in the environment is based on cognitive approaches; education for the environment includes action-based initiatives (Mertz, 2010). Mertz argued that:

Teaching about the environment addresses knowledge outcomes such as those found in curriculum documents; teaching for the environment concerns teaching that results in action to improve or benefit the environment, and teaching in the environment includes activities that take place outside of the classroom in a natural locale. (Mertz, 2010, p. 156)

\section{Environmental education: pedagogical implications}

Policy implementation depends on teachers' beliefs in teaching socially-based issues such as education for the environment (Hart, 2002).As Wellington (2001) stated:

Any process of policy-making and curriculum planning, however deliberate and controlled, is always mediated by and through the teaching profession. Teachers' response to plans, policies, and statements of aims is the final determining factor in shaping practice and putting purposes into action. (p. 29)

The Ministry of Education enacts policy, but it is the job of the teacher to implement it in the classroom. Some teachers teach it as a moral responsibility to the environment, others as doing social justice to the environment and society. Few teachers know about the principles of environmental education as defined in policy documents such as the Belgrade Charter, the Brundtland Report, or Agenda 21 (Hart, 2002) or about nationallyconstructed strategies. Teachers who have internalized the ethic of care incorporate environmental issues into science curriculum.

The implementation and incorporation of environmental education into the curriculum depends on a myriad of factors including teachers' attitudes and beliefs in teaching environmental education, the orientation of environmental education (i.e. environmental education is transformative in nature and goes counter to the present curriculum which is based on a social reproduction model (Hart, 2002), a lack of time to teaching it due to an already overburdened curriculum , a lack of resources (Johnston, 2009; Metz et al., 2010), lack of funding for education in the environment (Metz et al., 2010), lack of teacher training, and a lack of collegial and administrative support (Puk; Makin, 2006). In an age when teachers should be activists for environmental change, the idea that "environmental education crosses traditional disciplinary boundaries and involves underlying interests and attitudes innocent or even contrary to broad science issues related to social reproduction" (p. 1246) should be easily overcome. Teaching environmental education should be done 
by stepping outside the curriculum box (Johnston, 2009). Stepping outside the curriculum box means environmental education about/in/and for the environment (Metz, 2010).

According to Hart (2002), a holistic curriculum incorporates the environmental dimension. Teachers should be aware of the environmental education they provide: "This involves the personal/pedagogical struggle to uncover our taken-for-granted assumptions about teaching and learning which drive our pedagogical activities" (p. 1247).

Environmental education represents a worldview that is ontologically distinct from science education, a philosophy that compels participation in socio-democratic action. Environmental education for social change has to be considered as critical education which considers teaching as a project of research in action. Environmental issues can be explored critically from ethical as well as scientific viewpoints (Hart, 2002, p. 1248).

There is an urgent need for transformative environmental education and actionbased environmental participation. Schools should be vested with an environmental mission about/for/in the environment.

Another issue outlined throughout the research literature in science education is a lack of research on science education. Tiblisiplus urges researchers and science educators to reframe their objectives for environmental education. These objectives include:

1.Change thinking about education and learning;

1.8 Help people to review values in relation to policy and behaviour through mandatory interdisciplinary and/or trans-disciplinary courses of learning for sustainability that employ new research and pedagogical approaches.

2. Change patterns of leadership and partnership formation

2.4. Generate educational practices and research that lead to solutions for crossborder environmental problems and stronger environmental education and ESD practices and local, national and global levels through inter-country and regional exchange and cooperative support within a partnership framework

6. Change sites of learning and participation patterns and practices.

6.6. Integrate emancipatory, participatory and other transformative research approaches into international, national and institutional research agenda (EditorialEnvironmental Education Research, 2009, p. 134-135).

Scott (2009) argued that "environmental education research needs to demonstrate its significance to the real world and the environmental and development problems that are current" (p. 138). Within this context, environmental education should be informed by the latest research in the field. Since environmental education research is such a slowly progressing field, how will it inform research? As the Editorial shows: "we seem to know a little but not enough about the complexities of the links and relationships and flows between research insights, policy demands and practice configurations in this field" (Tiblisplus, 2009, p. 150).

\section{Why is science curriculum believed to be a limited vehicle for EE enactment?}

Gough (2002) outlined five reasons why science education is limited in scope: a) a global trend towards standardized curricula that further removes teachers' abilities to plan their own curriculum, b) the content of science curriculum as heavily influenced by the science community in its desire to further tertiary studies; c) EE requires inclusion in an 
already crowded curriculum d) selective teachings of EE topics, e) science educators don't have the same knowledge and background as environmental educators.

As evidenced in Steele's (2010) study, teachers' difficulties to incorporating EE within the science curriculum steams from varied contexts: their beliefs about the discipline of science as "a politically neutral and rule-structured human endeavour that values knowledge as sacrosanct" (p. 10); "the culture of secondary science teachers, steeped in the tradition of science is a powerful deterrent to meaningful change in science teaching" (p. 11); heavy reliance on textbooks as the main pedagogical tools; teachers' beliefs about EE as requiring specialized knowledge which they may not posses makes them regard it as "an add-on to the regular science-program" (p. 15), and, lack the knowledge necessary to consider the political, social, and economic ramifications of EE (Steele, 2010).

The incorporation of EE within science education and across the curriculum span requires a strong ethical commitment on behalf of the teachers as the primary sources of change. As the study implemented by Barrett and Pedretti (2006) revealed, locally developed STSE courses can be successfully implemented if teachers have strong ethical commitments toward EE integration into their curricular platform. Furthermore, the locallydeveloped STSE course had a social transformative role; it combined critical thinking skills with action. As Barrett \& Peddretti (2006) argued "co-creating a more equitable and just society should be the goal of education and STSE education" (p. 244) and teachers have the power to engage in these transformative discourses.

According to the Environmental education: scope and sequence expectations (2009), EE is infused in the following disciplines: The Arts, Business Studies, Canadian and World Studies, Classical Studies, English, English as a Second Language and English Literacy Development, French as a Second Language, Guidance and Career Education, Interdisciplinary Studies, Mathematics, Native Studies, Science, Social Sciences and Humanities, and Technological Education. The problem is not that it is not embedded in the curriculum, but that some teachers find different reasons for not implementing it. The curriculum for Science is in the revision queue.

\section{Suggestions to incorporating EE into everyday teaching practice}

Among the ingredients for a successful integration are: a powerful structure for professional development; supportive collegial and administrative relationships that are conducive to successful integration; more autonomy granted to teachers "to focus their professional development efforts" (Steele, 2011, p. 18). Additionally, an EE integration requires a strong social network that purports strong allegiance to the environment; a strong environmental philosophy for teachers and students; networking with other stakeholders; bridging research and praxis and filling in the gaps with recent research (Stevenson, 2007); education for, in, and about the environment (Metz, 2010); and allocation of resources for EE (Metz, 2010; Stevenson, 2007). Stevenson (2007) argued that merging EE into the science education requires engaging a socially-critical ideology (with a political agenda grounded in social change). This will require "to indentify tensions in teachers' work that might be developed and exploited for creating spaces for environmental education practice" (p. 274). Other artifacts that bolster implementation include: the use of technology, awareness of constructivist learning and postmodernism that postulate that knowledge is socially constructed, new approaches to teacher 
professional development that emphasizes the importance of community partnerships in $E E$, curriculum strategies that resonate with the aims of EE, and partnerships between schools and stakeholders' (community and NGOs) in EE that stress the importance of social justice for the environment (Stevenson, 2007). As Stevenson said

educators cannot meet the challenge of engaging in teacher or student environmental education alone. They need networks of assistance and support, preferably in a broad social movement that not only can build collective expertise and commitment to learning about the creation of sustainable communities and societies, but also signals to politicians, policymakers and the public at large that schools should recapture their moral purpose of serving the public or common good. (p. 283)

Similar concerns have been echoed at an international level. Both international and National American Association of Environmental Education recognized that the integration of EE should be accomplished in both educational and non-educational settings and it should focus on three salient goals:

1) building awareness among ecological practices on the environ-ment; 2) providing education opportunities for citizens so they acquire the necessary skills, knowledge, values and attitudes for the protection of the environment; and, 3) fostering action-oriented behaviours towards environmental conservancy and sustainability. (Campbel et al., 2010, p. 5)

Research studies highlight the need for teachers' professional development in teaching environmental issues (Yueh and Jones, 2010). According to Supovitz and Turner (2000), effective professional development include inquiry-based learning, enhancement of teacher's content knowledge skills, and clear and tangible links to classroom practice (in Yueh; Jones, 2010).

\section{Conclusion}

The incorporation of environmental issues into science curriculum requires micromacro level changes that will bolster successful integration. Further research on examining the gap between policy and practice after implementing the above-mentioned concerns is needed to determine future steps to tackle these issues.

\section{References}

BARRETT, S. E. and PEDRETTI. Contrasting orientations: STSE for social reconstruction or social reproduction? School Science and Mathematics Journal. 106 (5), 2006, p. 237247.

CAMPBELL, T; MEDINA-JEREZ, W; ERDOGAN, I; ZHANG, D. Exploring science teachers' attitudes and knowledge about environmental education in three international teaching communities. International Journal of Environmental and Science Education. 5 (1), 2010, p. 3-29.

EDITORIAL: Environmental education research: will the ends outstrip the means? Environmental Education Research, 15 (2), p. 129-153.

FERKANY, M; WHYTE, K. P. The compatibility of liberalism and mandatory environmental education. Theory and Research in Education, 11 (1), 2013, p. 5-21. 
GOUGH, A; SHARPLEY, B. Toward effective teaching and learning: stories of primary schools' environmental science interest and action. Educational Action Research, 13 (2), 2005, p. 191- 211.

HART, P. Environment in the science curriculum: the politics of change in the PanCanadian science curriculum development process. International Journal of Science Education, 42 (11), 2002, p. 1239-1254.

JOHNSTON, J. Transformative environmental education: stepping outside the curriculum box. Canadian Journal of Environmental Education, 14, 2009, p. 149- 195.

HODSON, D. Time for action: science education for an alternative future. International Journal of Education, 25(6), 2003, p. 645-670.

HODSON, D. The History, traditions and values of science. In: Teaching and learning about science: language, theories, methods, history, traditions, and values. Rotterdam: Sense Publishers, 2009.

METZ, D; MCMILLAN, B; MAXWELL, M; TETRAULT, A. Securing the place of educating for sustainable development within existing curriculum frameworks: a reflective analysis. Canadian Journal of Environmental Education, 15, 2010, p. 150- 169.

MICHAEL, P. M; PATTILLO, K. K; MITCHELL, D. B; LUTHER, R. A. Lessons from the tree that owns itself: implications for education. International Journal of Environmental and Science Education. 6 (3), 2011, p. 293-314.

MOLSEMI, J. I; CAPPS, K. A; JOHNSON, M.S; MAUL, J; MCINTYRE, P. B; MELVIN, A. M; VADAS, T. M; VALLANO, D. A; WATKINS, J. M., AND WEISS, M. Training tomorrow's environmental solvers: an integrative approach to graduate education. BioScience, 59(6), 2009, p. 514- 521.

PUK, T; MAKIN, D. Ecological consciousness in Ontario elementary schools: the truant curriculum and the consequences. Applied Environmental Education and Communication, 5 (4), 2006, p. 269-276.

POULIOT, C. Using the deficit model, public debate model and co-production of knowledge models to interpret points of view of students concerning citizens' participation. In Socioscientific Issue. International Journal of Environmental \& Science Education, 4 (1), 2009, p. 49-73.

STEELE, A. Beyond contradiction: Exploring the work of secondary science teachers as they embed environmental education in curricula. International Journal of Environmental \& Science Education. 6 (1), 2010, p. 1-22.

STEVENSON, R. B. Schooling and environmental/sustainability education: from the discourses of policy and practice to discourses of professional learning. Environmental Education Research, 13 (2), 2007, p. 265-285.

WELLINGTON, J. What is science education for? Canadian Journal of Science, Mathematics and Technology Education, 1 (1), 2001, p. 23-38.

YUEH, M.C.M; COWIE, B. What influences the emergence of a new subject in schools? The case of environmental education. International Journal of Environmental Education. 5 (3), 2010, p. 265- 285. 
Mihaela Lacob is an independent researcher and prospective PH.D. Student with areas of research interests in knowledge mobilization (KMb), large-scale educational reform, research brokering organizations, and educational leadership. Address: 226 Lilac Bay, Winkler - Manitoba - Canada.

E-mail: michaelaiaco@yahoo.com.

Recebido em 22 de julho de 2013.

Aceito em 3 de setembro de 2013. 